\title{
POTENTIAL OF CURCUMA LONGA EXTRACT TO THE GROWTH OF SALMONELLA STAPHYLOCOCCUS AND BACILLUS SUBSTILIS ON PELOR EXTRACT
}

\author{
Siswi Astuti ${ }^{1 *}$, Nanik Astuti Rahman ${ }^{1}$, Endah Kusuma Rastini ${ }^{2}$ \\ ${ }^{1}$ Chemical Engineering, National Institute of Technology (ITN) Malang, Indonesia \\ ${ }^{2}$ Mechanical Engineering, National Institute of Technology (ITN) Malang, Indonesia
}

*Corresponding Email: siswiastuti@lecturer.itn.ac.id

\begin{abstract}
People with autism are sensitive to milk protein (casein), gluten, and sugar. These foods can cause an increase in aggressive behavior, crying, anger, stress and depression, while also able to increase digestive disorders, allergies and neurobiological disorders in people with autism. Trials have been carried out on several autistic people by providing food based on MOCAF modified with Centella Asiatica extract with positive results. Children are more focused, more communicative and the symptoms of stress and depression decrease. The weakness is that it can still lack the necessary vitamins and minerals so that it is continued with the manufacture of supplements made from Centella Asiatica and egg extracts (PELOR). Those contain vitamins and minerals needed by people with autism and do not form new compounds but still contain microbes. The research was done by giving various concentrations of $5 \%, 10 \%, 15 \%, 20 \%, 25 \%, 30 \%$ and $35 \%$ curcuma longa in pelor extract which is expected to reduce microbial growth. The results concluded that PELOR extract with the addition of $20 \%$ curcuma longa can kill the growth of harmful microorganisms of Salmonella and Staphylococcus but it is still not effective in inhibiting the growth of Bacillus substilis. In the addition of $20 \%$ curcuma longa, there was Bacillus substilis with a total of $3 \times 103$ colonies/100ml or an NPN value of 0.03 has met the SNI 7388: 2009 standard. Therefore, it was concluded that it was safe to potentially be a balanced nutritious supplementary food needed by people with autism.
\end{abstract}

Keywords: Curcuma longa extract, PELOR extract, salmonella, staphylococcus

\section{Introduction}

Food diversification is mostly done to increase food diversity and human nutritional needs can be obtained from plants and animals and their processed waste. This activity is carried out continuously in order to meet food selfsufficiency in the country due to increasing population growth and the impact of changing seasons. This nutritional requirement is also needed by people with special needs where not all food ingredients can be consumed by them. People with special needs are very sensitive to several different foods from society in general. One of the people with special needs is a person with autism. They are not allowed to consume too much protein from milk and its derivatives, sugar, gluten even though this material is highly nutritious [1]. Therefore, it is necessary to find alternatives to replace these materials.
Autism is a broad neurobiological development disorder in children which includes communication disorders, social interactions, imagination, and repetitive behavior patterns and does not easily adapt to change [2]. The causes of this disorder derived from the environment and genetics. One of the triggers for the onset of autism is that the food consumed causes digestive disorders and allergies, which results in more aggressive, crybaby, irritable behavior [3],[4]. This condition make many parents get some difficulties, supervise diet and worry for giving diet food and supplements [5],[6].

Trials of giving food based on MOCAF modified with Centella Asiatica extract had been carried out with the results that children are more focused, can see their interlocutors, are more communicative, and can reduce symptoms of stress and depression [7],[8],[9],[10]. The trial was continued again so that the need for vitamins and minerals was also fulfilled by making supplements from fermented Centella Asiatica 
extract mixed with eggs (PELOR) [10]. From the analysis of the PELOR content test, it was concluded that no new compounds were formed as a result of mixing Centella Asiatica extract and fermented eggs. PELOR contains minerals and vitamins needed by people with autism. So that this supplement made from Centella Asiatica and eggs can be given to people with autism, but because the product comes from organic ingredients, it quickly gets damaged so it needs to be given preservatives that are safe for people with autism. Therefore, it is necessary to research the use of Curcuma Longa Extract on Changes in Nutritional Content of PELOR Extract and Growth of Salmonella and Staphylococcus.

Supplement therapy is intended for the cleansing process of the digestive tract, body metabolism and brain metabolism. The process of cleaning the digestive tract is given digestive enzyme therapy, for amino acids, detoxification, fatty acids, vitamins, minerals, body metabolism therapy is given. Brain metabolism therapy is done by administering Piracetam, Piritinol.

In order to know the types of foods that are not consumed, laboratory checks and rotation and elimination diets are necessary. The results of research on children with autism resulted in findings of abnormalities in metabolic patterns and dysfunction, such as:

1. Digestive System Dysfunction (diarrhea)

2. Nero inflammation, decreased blood flow to several parts of the brain, abnormalities in brain size.

3. Hormonal disorders, increased production of coetisol, serotonin and dopamine disorders.

4. Oxidative stress, decreased methionine which indicates a decrease in methylation capacity, increased homocysteine, decreased glutathione, increased lipin peroxidation, decreased levels of B12.

5. Mitochondrial disfunction: decreased levels of carnitine and increased lactate.

The increase in these symptoms can be observed from the aspects of speech, behavior, cognition, attention, and general health [11]. Consqeuently, it is necessary to look for supplements that come from natural ingredients considering the impact of non-natural medicines is very heavy.

Supplements needed for people with autism can be in the form of minerals or a combination of minerals so that nutritional intake can be balanced, but supplementation is adjusted according to laboratory examination results and levels according to age and body weight. After the supplementation is carried out, all symptoms that occur are identified and compared with the original condition to find out if there are positive changes.

Research result by Cornnish and Herndon [12] concluded that children with autism are mostly deficient in calcium, iron, vitamin $\mathrm{A}$, vitamin $\mathrm{C}$, vitamin $\mathrm{B} 6$, vitamin $\mathrm{E}$, zinc, amino acids niacin and ribovlavin, phosphorus and protein that are not derived from casein and flour. These minerals are found in eggs and Centella Asiatica so that when the two are mixed it can produce a balanced nutrition for people with autism. The results showed that mixing Centella Asiatica and eggs did not cause the formation of new compounds which could be fatal when used as supplements [13].

Eggs are the most preferred source of animal protein by people at a relatively affordable price. Eggs consist of $13 \%$ protein, $12 \%$ fat and vitamins and minerals. The egg quality is determined by the quality of the inside, namely the consistency of the egg white and yolk, the position of the yolk, the presence or absence of spots and the outside, namely the shape, skin color, egg surface, integrity, and cleanliness of the egg shell. Eggs have the best natural durability because they have a chemical and physical barrier against microbial infection to protect the poultry embryos so that their growth is guaranteed. But if an egg is cracked or broken, the natural protection will be lost and become a perishable food ingredient [14],[15]. Destructive microbes that can infect eggs are salmonella, staphylococcus Arizona. Egg damage results from bacteria and mold resulting from storage at air temperature for several weeks or storage in the refrigerator for several months. The main cause of microbial damage is the washing of dirty eggs before they are marketed because bacteria can enter to reproduce and damage. Reducing bacteria is done by freezing eggs and thawing again, but there are microbes that are resistant in these conditions, namely bacillus, alcaligenes and proteus, salmonella.

Curcuma Longa Linn is one of the natural ingredients that is often used in cooking mixtures, food coloring, fish odor remover in seafood. Curcuma longa has a turmeric foreign name and a synonym for Curcuma Domestica val. Curcuma longa in Indonesia is known as Kakunye, kunyet, kuning, hunik, under, turmeric, odi, turmeric, temo koneng. Plant parts that are often used are rhizomes and leaves with curcuminoid dye which is a $34 \%$ diaryheptanoid compound consisting of curcumin, dihydro curcumin, demetoxy curcumin and bisdesmetoxy curcumin; essential oils $2-5 \%$ consisting of sesquiterpenes and phenylpropane derivatives of turmerone (aryl-turmerone, alpha turmerone and 
beta turmerone), curcumol curlone, atlanton, bisabolen, sestuifellandren, zingiberin, aryl curcumen, humulene; Arabinose, fructose, glucose, starch, tannins and dammar; and minerals, namely magnesium, iron, manganese, calcium, sodium, potassium, lead, zinc, cobalt, aluminum and bismuth [16].

The benefits of curcuma longa are anticoagulant, anti-edemic, lowering blood pressure, malaria medicine, worm medicine, stomach pain medication, increasing breast milk, stimulant, treating sprains, bruises and rheumatism, analgesic, anti-inflammatory, anti-oxidant, antibacterial [17]. Curcuma longa can also maintain the quality of flying fish by immersing it at the best concentration of 200 grams in $1000 \mathrm{ml}$ of water [18]. Based on the above studies, it can be concluded temporarily that curcuma longa can be used as a preservative for PELOR extract because it has anti-bacterial compounds.

\section{Research Methods}

In this study, Curcuma longa in the form of extract powder was mixed with liquid Centella Asiatica extract which had been mixed with eggs in a certain ratio and then dried at a temperature of $50^{\circ} \mathrm{C}$. It was estimated that the Centella Asiatica egg extract could still contain salmonella and staphylococcus microbes which are usually present in chicken eggs. The highest content of curcuma longa was diarylheptanoid 3$4 \%$ which has antihepatotoxic, enthelmintic, antiedemic, analgesic, anti-inflammatory and antioxidant properties so that it was hoped to be able to overcome the possibility of microbial growth in the body of persons with autism. With the addition of curcuma longa, it was hoped that these microbes will die so that the egg pegagan extract supplement (PELOR) did not contain pathogenic microbes. No new compounds that can harm the users of this supplement were formed. The method used was an experimental method by providing treatment with curcuma longa concentrations ranging from 5\%, $10 \%$, $15 \%, 20 \%, 25 \%, 30 \%$ and $35 \%$ in PELOR extract, then analyzed the growth of Salmonella and Staphylococcus using the tube method and the plate method. The best results were in the analysis of its nutritional content.

\section{Result and Discussion}

The results of PELOR extract derived from 2.3 grams of organic egg liquid fermented with $0.3 \%$ yeast (saccaromyces cerevisae), added with
0.7 grams of Centella Asiatica extract then dried, obtained 2.3 grams of pelor extract powder. The resulting PELOR extract powder was then analyzed using SEM EDAX, the results of the observations obtained the following composition data:

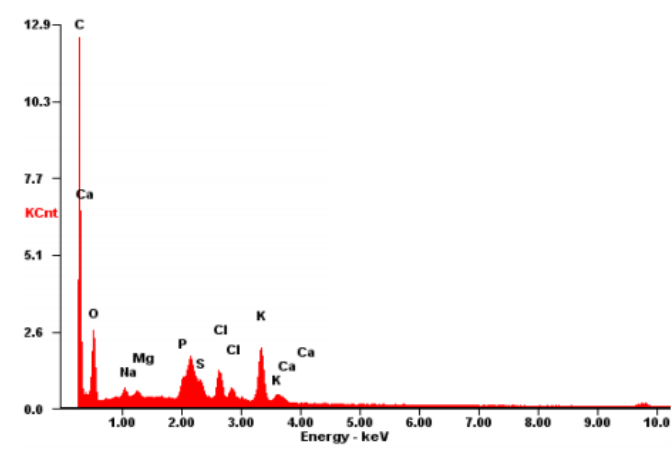

Figure 1 SEM EDAX analysis for mineral content in PELOR extract

Table 1 Mineral content in PELOR extract

\begin{tabular}{|c|c|c|c|}
\hline Element & $\begin{array}{l}\% \\
\text { (weight) }\end{array}$ & $\begin{array}{l}\text { No Element } \\
\text {. }\end{array}$ & $\begin{array}{l}\% \\
\text { (weight) }\end{array}$ \\
\hline$\overline{\mathrm{C} \text { (Carbon) }}$ & 56.46 & 6. P (Phosphor) & 01.81 \\
\hline $\mathrm{O}$ (Oxigen) & 27.33 & 7. S (Sulphur) & 02.86 \\
\hline $\mathrm{Na}$ (Natrium) & 01.68 & 8. $\mathrm{Cl}$ (Chlorine) & 06.15 \\
\hline$\overline{\mathrm{Mg} \text { (Magnesium) }}$ & 00.92 & 9. K (Potassium) & 00.76 \\
\hline$\overline{\mathrm{Al} \text { (Aluminium) }}$ & 02.02 & & \\
\hline
\end{tabular}

Furthermore, PELOR extract powder was analyzed for the types of microbes contained in the supplement using 2 (two) methods, namely the tube method and the plate method. The observations from both methods showed that the initial Centella Asiatica powder contained Salmonella Sp with an MPN value of 0.03 while the initial organic egg liquid contained Staphylococcus aureus with an MPN value of 0.03 as well as the PELOR extract with the same value. Bacillus Substilis was found in Centella Asiatica powder, Centella Asiatica extract and Curcuma Longa extract while in organic egg liquid there was no Bacillus Substilis. Curcuma Longa was added to increase the mineral content in PELOR extract, and kill the microbes in the pelor extract mixture and the preservation of PELOR extract and tested with a comparison certain namely 5\%, 10\%, 15\%, 20\%, 25\%, 30\%, $35 \%$. The results of the observations could be seen in Table 2. 
Table 2 Effect of Addition of Curcuma Longa Extract on Growth of Salmonella and Staphylococcus

\begin{tabular}{llll}
\hline $\begin{array}{l}\text { PELOR } \\
\text { extract } \\
\text { powder } \\
\text { gram) }\end{array}$ & $\begin{array}{l}\text { Curcuma } \\
\text { Longa extract } \\
\text { gram) }\end{array}$ & $\begin{array}{l}\text { Salmonella } \\
\text { Staphylo } \\
\text { coccus }\end{array}$ \\
\hline 2.00 & $0.1(5 \%)$ & - & - \\
\hline 2.00 & $0.2(10 \%)$ & - & - \\
\hline 2.00 & $0.3(15 \%)$ & - & - \\
\hline 2.00 & $0.4(20 \%)$ & - & - \\
\hline 2.00 & $0.5(25 \%)$ & - & - \\
\hline 2.00 & $0.6(30 \%)$ & - & - \\
\hline 2.00 & $0.7(35 \%)$ & - & - \\
\hline
\end{tabular}

The results of the analysis in the table showed that the addition of Curcuma Longa could kill Salmonella and Staphylococcus at the lowest concentration of $5 \%$ because curcumin could disrupt the cell cycle and suppressed cell growth whose strength depended on the concentration. The effect of its strength was not only on its non-specific cytotoxic strength but also on the induction of apoptosis [19]. Curcumin has the ability to inhibit COX [20] as inhibitor of cell proliferation and antiangiogenesis. The weakness of Curcuma Longa is that it cannot kill the bacillus substilis. This will cause the bacillus substilis that initially exists in the raw material remains in the product: the higher the concentration of curcuma longa, the higher the concentration of bacteria was. This happened as this food product could provide good nutrition for the growth of bacillus substilis (table results observation 3). Therefore, it was necessary to add other compounds from herbal plants that have bioactive properties.

Table 3 Effect of Addition of Curcuma Longa Extract on the Growth of Bacillus Substilis

\begin{tabular}{llll}
\hline $\begin{array}{l}\text { PELOR } \\
\text { extract } \\
\text { powder } \\
\text { (gram) }\end{array}$ & $\begin{array}{l}\text { Curcuma } \\
\text { Longa } \\
\text { extract } \\
\text { gram) }\end{array}$ & $\begin{array}{l}\text { Bacillus } \\
\text { Substilis } \\
\text { Microbes } \\
\text { (colony/100 } \\
\text { ml) }\end{array}$ & $\begin{array}{l}\text { NPN } \\
\text { Value }\end{array}$ \\
\hline 2.00 & $0.1(5 \%)$ & $20 \times 10^{4}$ & 0.2 \\
\hline 2.00 & $0.2(10 \%)$ & $12 \times 10^{4}$ & 0.12 \\
\hline 2.00 & $0.3(15 \%)$ & $14 \times 10^{4}$ & 0.14 \\
\hline
\end{tabular}

\begin{tabular}{llll}
\hline 2.00 & $0.4(20 \%)$ & $3 \times 10^{3}$ & 0.03 \\
\hline 2.00 & $0.5(25 \%)$ & $20 \times 10^{4}$ & 0.20 \\
\hline 2.00 & $0.6(30 \%)$ & $61 \times 10^{4}$ & 0.61 \\
\hline 2.00 & $0.7(35 \%)$ & $61 \times 10^{4}$ & 0.61 \\
\hline
\end{tabular}

Bacillus substilis is a non-pathogenic bacteria class that could be useful for maintaining the balance of microbes in digestion. However, excessive Bacillus substilis can cause diarrhea, therefore making supplements with the addition of curcuma longa is good for the addition of $20 \%$ Curcuma Longa. The inhibition of colony growth was due to damage to the structural components of the bacterial cell membrane. Terpenoid class compounds could bind to proteins and lipids contained in the cell membrane because terpenoids can reduce surface tension that it could disrupt the transport of nutrients both in the form of compounds and ions through the cell membrane so that Bacterial cells experience a lack of nutrients in their growth. In the increase of the addition of Curcuma Longa, there was also an increase in the number of bacillus substilis bacteria. This happened because Curcuma longa can inhibit cell growth but cannot reduce surface tension so that the transfer of nutrients for bacterial growth continues. The Indonesian national standard for dietary food products specifically for the health needs of infants and children in the form of instant powder made from herbal ingredients and eggs, the maximum limit of microbial contamination in food for Salmonella $\mathrm{Sp}$ : negative/25 grams, Staphylococcus Aureus 1x102 koloni/gram and Bacillus Cereus $1 \times 10^{4}$ koloni/gram [21]. The results of the study were only $3 \times 10^{3}$ colony/gram Bacillus substilis for the addition of $20 \%$ curcuma longa, therefore it can be concluded that the supplement mixture of Centella Asiatica extract, organic eggs and curcuma longa was safe for consumption by persons with autism.

\section{Conclusions}

\subsection{Conclusion}

The results showed that PELOR extract with the addition of $5 \%$ curcuma longa was able to inhibit the growth of harmful microorganisms, namely Salmonella and Staphylococcus but could not inhibit the growth of Bacillus substilis. The higher the concentration of Curcuma Longa the more Bacillus substilis, but these bacteria are 
classified as probiotic bacteria. It functions to maintain the microbial balance of the digestive tract so that supplements containing Centella Asiatica, egg and curcuma longa extracts can have the potential to be a nutritionally balanced supplementary food, can kill non-pathogenic microbes, reduce inflammation and contain antioxidants and contain the minerals zinc, iron, calcium, phosphorus needed people with autism. However, excessive probiotic bacteria can cause diarrhea so that the best result in this study is the addition of $20 \%$ curcuma longa.

\subsection{Suggestion}

To get optimal results regarding the nutritional value of PELOR extract supplements that are safe for consumption and long-lasting, it is necessary to conduct more research by utilizing secondary metabolite compounds found in herbal plants containing flavonoids, phenols, terpenoids, and essential oils which can reduce the growth of Basillus Substilis. The results obtained then will provide information on the concentration of how much curcuma longa and herbal ingredients concentration are able to serve as a probiotic supplement but low in Bacillus Substilis and can provide information about the expiration of PELOR extract.

\section{REFERENCES}

[1] Ayu, Gusti. 2011. Pentingnya Pengaturan Makanan Bagi Anak Autis. Penerbit Poltekkes, Denpasar.

[2] Mulyadi K, R Sutadi. 2014 Autism is Curable Jakarta:Gramedia

[3] Aritonang E, Pardede A, Ervika E. 2009. Pengetahuan, Sikap dan Tindakan Ibu dalam Pola Makan Anak Penyandang autis di Yayasan Tali Kasih. Jurnal Kedokteran Indonesia, Vol.1 No.1.

[4] Jasaputra, Diana K. 2003. Alergi Makanan Pada Anak Autis. Kongres Nasional Autisme Indonesia Pertama. Jakarta: Pusat Informasi dan Penerbitan Bagian Ilmu Penyakit Dalam Fakultas Kedokteran Universitas Indonesia.

[5] Ratnadewi. 2010. Peran Orang Tua pada Terapi Biomedis untuk Penyandang Autis, Jurnal; Fakultas Psikologi, Universitas Gunadarma, Jakarta.

[6] Suswati, Irma. 2011. Diet Rotasi Makanan Dan Manifestasi Klinis Penyandang Spektrum Autisme. Penerbit UMM, Malang.
[7] Jamil, S.S., Nizami, Q., Salam, M. 2007. Centella asiatica (Linn.) Urban Review, Artikel; Faculty of Medicine (Unani), Hamdad University, New Delhi, India

[8] Mora, E., Fernando, A. 2012. Optimasi Ekstraksi Triterpenoid Total Pegagan'; (Centella asiatica (Linn.) Urban) yang Tumbuh di Riau, Jurnal Penelitian Farmasi Indonesia, Sekolah Tinggi Ilmu Farmasi Riau, Pekanbaru.

[9] Suganda, A.G., Hakim, L., Santosa, S, D., Elfahmi. 2012. Pedoman Teknololgi Formulasi Sediaan Berbasis Ekstrak,Volume 1. Direktorat Obat Asli Indonesia, BPOM RI, Jakarta.

[10] Astuti, et al., 2016. Efektivitas Ekstrak Pegagan (Centella Asia Tica) untuk Meningkatkan Kandungan gizi Tepung yang Termodifikasi; Astuti, et al., 2017 Ekstrak PELOR sebagai Alternatif Suplemen Penyandang Autis.

[11] Suryana. 2004. Hubungan Antara Konsumsi Casein, Gluten dan Pola Aktivitas yang Khas Pada Anak Penyandang Autis. Denpasar: Dewan Pimpinan Pusat (Persagi).

[12] Cermak SA, Curtin C, Bandini LG. 2010. Food Selecvtivity and Sensory Sensitivity In Children With Autism Spectrum Disorders. J Am Diet Assoc. 110(2): 238246

[13] DarsonoSigit al., Vol 5(Iss.4): April, 2018. Control Effect of Pori Structure on Triterpenoid Modification in Mocaf; Global Journal of Advanced Engineering Technologies and Sciences.

[14] Winarno, F.G dan S. Koswara, 2002. Telur, Penanganan dan Pengolahannya. M- brio Press, Bogor

[15] Koswara, K. 2009. Teknologi Pengolahan Telur. E Book Pangan.com Mulyadi, K, Sutadi, R. 2014. Autism is Curable. Jakarta: Gramedia.

[16] Sudarsono et.al, .1966. Tumbuhan Oba, Hasil Penelitian Sifatsifat dan Penggunaan. Yogyakarta: PPOT-UGM

[17] Louay Labban, 2014 Medicinal and Pharmacological Properties of Tumeric (Curcuma Longa): A review Int $j$ Pharm biomed SCI 2014: 5 (1) : 17-23

[18] Pasaraeng, E., et al., 2013. Pemanfaatan Rimpang Kunyit (Curcuma Domestica Val) dalam upaya mempertahankan Mutu Ikan Layang (Decapterus SP).

[19] Ankur Gupta, Surabhi Mahajan, Rajendra Sharma, 2015 Evaluation of Antimicrobial Activity of Curcuma longa rhizome extract against Staphylococcus 
aureus. Biotechnology Reports Volume 6, June 2015, Pages 51-55

[20] Meiyanto, 1999. Kurkumin sebagai Obat Kanker Menelusuri Mekanisme Aksiny (Curcumin as an Antineoplastic Agent: The Elucidation of Its Molecular Mechanism of Action).

[21] SNI 7388 : 2009 Batasan Maksimum Cemaran Mikroba Dalam Pangan 